\title{
PENGARUH INJEKSI SEMEN PADA LERENG TANAH BERPASIR TERHADAP PERMEABILITAS TANAH
}

\author{
I Wayan Arya ${ }^{1, *)}$, I Wayan Intara1), I Nyoman Ramia ${ }^{1)}$, I Wayan Wiraga ${ }^{1)}$, \\ I G A G Suryanegara ${ }^{1)}$ \\ 1) Jurusan Teknik Sipil Politeknik Negeri Bali \\ Jl. Raya Kampus Udayana, Bukit Jimbaran, P.O. Box 1064 Tuban Badung Bali \\ ${ }^{*}$ Email: wayanarya@pnb.ac.id
}

\begin{abstract}
Natural slope that are formed from the soil often experience landslides. Landslide occurs because the driving force received by the slope is greater than the ability of the slope to resist it. Thus forming a sliding plane that has a low stability. Factors that decrease the stability of the slope are infiltration of rainwater, vibrations that may come from earthquakes or moving loads, construction loads, and cracks. Rainwater that infiltrate through slope causes active force on the slopes and also decreases soil strength. Landslides due to infiltration of rainfall are common problems on residual soil slopes from the tropical region. Soil stabilization process for soil that have been experienced prior landslide, often encounter difficulty in compacting soil to form slope bodies. Loose sandy soil slopes has a very low strength so that expensive construction is needed. One possible way to do this is to fill the pores of the soil with certain aggregates. One of the aggregates is cement. The cement material is chosen because cement when liquid can seep in and fill the pores of the soil. After drying this cement can increase soil permeability and reduce soil pore numbers. Filling cement into the soil pores can be done by injection of liquid cement. The problems that will be raised in this study are: What is the change in soil permeability rate if the soil is injected with cement and how much changes in soil pore size when injected with cement. The method used in this study is to make a test model in the laboratory. By comparing soil without cement injection with soil that has been injected with cement, it will be known to increase soil permeability and decrease the soil pore number. From the preliminary test with proctor test, the maximum density was 1,286 gram/cm3 and the optimum water content was $18 \%$. Decrease of coefisien permeability from without cement injection to with cement injection $31,5 \%$.
\end{abstract}

Kata kunci : injeksi semen, permeabilitas, angka pori, tanah pasir

\section{PENDAHULUAN}

Lereng adalah bagian dari topografi tanah yang terbentuk karena adanya perbedaan elevasi dari dua permukaan tanah. Lereng terdiri dari puncak lereng, kaki lereng dan dasar lereng. Kaki lereng bisa vertikal maupun membentuk sudut tertentu dengan bidang horisontal. Terbentuknya lereng bisa karena secara alami dan juga dapat karena dibuat oleh manusia untuk suatu keperluan teknis tertentu. Lereng alam banyak dijumpai diwilayah dataran tinggi.

Kondisi lereng alam yang terbentuk dari tanah sering kali 
mengalami kelongsoran. Kelongsoran lereng terjadi karena gaya penggerak yang diterima oleh lereng lebih besar dibandingkan dengan kemampuan lereng tersebut untuk menahannya, sehingga terbentuklah bidang geser yang memiliki stabilitas rendah. Faktor faktor pengganggu kestabilan lereng diantaranya adalah : air hujan, getaran yang mungkin berasal dari gempa bumi atau beban bergerak, beban konstruksi yang terbangun, rekahan tanah (crack). Air hujan yang masuk ke dalam tanah lereng menyebakan dorongan pada lereng dan juga menurunkan kekuatan tanah. Longsor karena induksi curah hujan adalah masalah umum di lereng tanah residual dari daerah tropis. Hal ini secara luas diketahui bahwa kegagalan lereng disebabkan infiltrasi curah hujan (Raharjo, 2015). Jika ada rekahan tanah pada lereng tersebut, maka kondisi ini akan lebih memperparah lagi stabilitas lereng. Menurut Chowdhury (2010) dua faktor utama penyebab ketidakstabilan dan kelongsoran lereng adalah intensitas curah hujan yang tinggi dan pergerakan tanah karena gempa bumi.

Pengaruh air terhadap stabilitas lereng karena sifat permeabilitas tanah, yaitu sifat tanah yang mampu dimasuki oleh air melalui pori pori tanah tersebut. air yang masuk ke pori tanah secara berlebihan akan membentuk gaya dorong atau gaya penyebab longsor dan juga sekaligus melemahkan kuat geser tanah. Kuat geser tanah adalah kekuatan tanah untuk melawan gaya geser yang meruntuhkan tanah tersebut.
Ketidakstabilan lereng akan mengandung resiko tersendiri terhadap aktifitas manusia bahkan mengancam jiwa manusia. Tingkatan risiko menurut Roy E. Hunt (2007) sebagai berikut : risiko rendah adalah sebuah ketidaknyamanan yang mudah diperbaiki, tidak secara langsung membahayakan kehidupan atau properti, seperti satu blok batuan dari ukuran kecil menghalangi sebagian kecil dari jalan dan mudah dihindari dan dihilangkan. Risiko sedang apabila terjadi gangguan lebih parah, ditangani dengan beberapa usaha, tetapi biasanya tidak langsung membahayakan kehidupan atau struktur ketika itu terjadi, Seperti puing - puing lereng memasuki salah satu jalur jalan dan menyebabkan penutupan sebagian untuk jangka waktu singkat sampai selesai disingkirkan. Berisiko tinggi: hilangnya seluruh atau sebagian dari jalan atau struktur penting, atau penutupan keseluruhan dari jalan untuk beberapa periode waktu, tapi tidak menghilangkan nyawa manusia. Resiko yang sangat tinggi bilaman mengancam hidup/nyawa manusia pada saat terjadi kelongsoran, misalnya, penghancuran struktur bangunan / rumah atau kereta api ketika tidak ada waktu untuk peringatan.

Setiap tahun di musim hujan selalu terjadi bencana tanah longsor di Wilayah Indonesia. Pada tahun 2016 beberapa bencana kelongsoran lereng terjadi di daerah Bali. Salah satu yang terparah dan masih belum selesai ditangani adalah kelongsoran lereng di Kecamatan Petang Kabupaten Badung, 
Bali. Seperti terlihat pada Gambar 1 bahwa kelongsoran lereng ini sampai mengahabiskan semua badan jalan, yang menyebabkan transportasi terputus dan mesti dialihkan ke jalan lainnya. Di jalur Denpasar Singaraja juga rutin terjadi tebing longsor yang sangat merugikan transportasi dan juga sampai merenggut koraban jiwa. Kerugain ekonomi dan kehilangan nyawa sudah banyak diakibatkan oleh tanah longsor. Usaha untuk mengatasi dan mencegahnya juga sudah banyak dilakukan dan masih terus dicari metode - metode untuk peramalan stabilitas lereng yang lebih akurat.

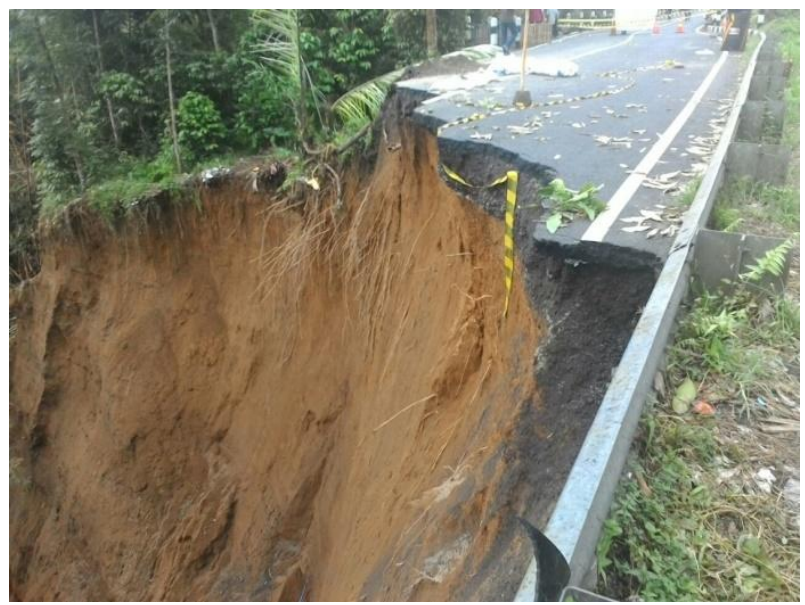

Gambar 1. Kondisi Longsor di Kecamatan Petang Kabupaten Badung.

Setiap kasus keteknikan selalu memberikan dorongan bagi ahli - ahli teknik untuk mencari penyebabnya, serta menemukan pendekatan penyelesaiannya. Untuk kasus kelongsoran lereng sudah banyak teori yang dikembangkan dan diusulkan untuk penangannya. Beberapa diantaranya adalah : dengan cara perkuatan yang konvensional berupa dinding penahan tanah, tiang cerucuk atau mikro pile, perkuatan dengan geotextile. Beberapa penelitian tentang pengaruh curah hujan juga sudah dilakukan. Penelitian yang lainnya juga meninjau pengaruh rekahan atau crack yang terjadi pada lereng sudah ditinjau.

Dalam penanganan perbaikan lereng yang telah longsor, sering kali mengalami kesulitan dalam hal pemadatan tanah untuk membentuk badan lereng. Tanah yang tidak padat untuk lereng tentu saja kekuatannya akan rendah sekali sehingga diperlukan konstruksi yang mahal. Salah satu cara yang mungkin dapat dilakukan adalah dengan mengisi pori - pori tanah dengan bahan tertentu. Salah satu bahan itu adalah semen. Bahan semen dipilih karena semen pada saat cair dapat meresap dan mengisi pori pori tanah. Setelah kering semen ini dapat memperkuat tanah sehingga lereng juga kuat. Mengisi semen kedalam pori - pori tanah dapat dilakukan dengan cara injeksi semen cair. Hasil penelitian Arya dkk (2018) mendapatkan terjadinya peningkatan kuat geser secara signifikan tanah berpasir yang diinjeksi semen. 
Perlu juga diperhatikan adalah permeabilitas tanah pada saat tanah dimasuki oleh air. Karena dengan masuknya air ke dalam pori tanah akan menyebabkan gaya dorong yang lebih besar dan kekuatan tanah akan menurun. Dengan demikian perlu diketahui pengaruh injeksi semen terhadap nilai permeabilitas tanah.

\section{METODE PENELITIAN}

\section{Rancangan Penelitian}

Pada penelitian ini digunakan rancangan penelitian yaitu metode ekperimental. Rancangan penelitian yang digunakan adalah dengan membuat model pengujian laboratorium yaitu menguji permeabilitas tanah asli, permeabilitas tanah yang dipadatkan dan permeabilitas tanah yang diinjeksi dengan semen. Sebagai acuan pembanding adalah tanah yang dipadatkan karena pekerjaan perbaikan lereng biasanya tanah dipadatkan. Rancangan kedua adalah tanah tidak dipadatkan tetapi diinjeksi dengan semen. Injeksi semen ini akan mengisi pori pori tanah sehingga tanah akan menjadi padat. Juga akan terjadi ikatan antar butir tanah dengan semen sehingga air tidak mudah masuk ke dalam tanah. Permeabilitas tanah akan mengecil. Mengecilnya permeabilitas tanah karena anggka pori tanah yang mengecil. Dirancang juga pariasi tekanan injeksi pada model tanah. Karena tekanan injeksi berpengaruh terhadap pengisian air semen ke pori pori tanah. Beberepa jenis tekanan injeksi akan diaplikasikan pada model tanah yang diinjeksi semen. Sehingga didapat pengaruh besarnya tekanan injeksi terhadapat permeabilitas tanah dan angka pori tanah.

\section{Ruang Lingkup Penelitian}

Karena luasnya permasalahan stabilitas lereng dan banyaknya variabel yang terlibat maka dalam penelitian ini perlu dibatasi sebagai berikut :

1. Lereng yang diteliti adalah lereng dari tanah berpasir.

2. Semen yang dipakai untuk bahan injeksi adalah semen PPC

\section{Penentuan Sumber Data}

Data yang dikumpulkan untuk penelitian ini adalah data primer berupa :

1. Data sifat fisis tanah tanah asli

2. Data sifat fisis tanah yang dipadatkan

3. Data sifat fisis tanah yang diinjeksi semen

4. Data sifat fisis semen bahan injeksi

5. Data permeabilitas tanah asli

6. Data permeabilitas tanah yang dipadatkan

7. Data permeabilitas tanah yang diinjeksi semen

8. Data kuat geser tanah yang sudah diinjeksi semen

\section{Variabel Penelitian}

Pada penelitian ini terdapat variabel bebas dan variabel tidak bebas yaitu :

1. Yang termasuk variabel bebas adalah tekanan injeksi semen.

2. Yang termasuk variabel tidak bebas adalah nilai peremeabilitas tanah dan angka pori tanah

\section{Bahan Penelitian}


Dalam penelitian ini bahan - bahan penelitian yang akan digunakan adalah

1. Tanah berpasir : adalah bahan utama pada peneltitian ini. Tanah ini berupa tanah berpasir yang seperti aslinya di lapangan. Bahan ini akan digunakan untuk membuat model uji di laboratorium.

2. Semen : adalah bahan untuk injeksi lereng yang dibuat pada model di laboratorium. Semen dipilih karena semen dapat mengisi pori - pori tanah pasir sehingga tanah menjadi lebih kedap dan tanah lebih padat.

\section{Prosedur Penelitian}

1. Pembuatan model lereng

a. Model lereng sesuai dengan aslinya dilapangan

Berdasarkan data property tanah lapangan, maka dibuatkan model lereng pada bak model yang sudah dipersiapkan. Dibiarkan sekitar 3 hari baru diberikan beban luar sampai lereng tersebut longsor. Pada model yang lain diambil sampel tanah untuk ditest kuat gesernya dengan uji direct shear. Hasil uji direct shear ini dipakai data tanah untuk analisa stabilitas lereng.

b. Model lereng sesuai dengan aslinya dan diinjeksi dengan semen
Model lereng dibuat sama seperti model yang di atas. Setelah terbentuk lereng diinjeksi dengan semen cair pada satu titik. Lereng didiamkan selama 3 hari kemudian dibebani sampai longsor. Satu lagi lereng yang sama dibuat untuk mendapatkan sampel guna uji direct shear.

Model berikutnya diinjeksi pada 2 titik dan 4 titik. Diperlakukan sama dengan lereng yang di atas.

\section{HASIL DAN PEMBAHASAN}

\section{Properti sample}

Penelitian ini menggunakan sample tanah yang diambil dari Kecamatan Petang Kabupaten Badung. Sebelum dijadikan sample tanah diayak dulu dengan ayakan $2 \mathrm{~mm}$ sehingga mendapatkan tanah pasir. Dilakukan uji proctor terhadap sample untuk mendapatkan kadar air optimum. Kadar air optimum ini yang akan dipakai untuk merancang model lereng. Dari pengujian proctor test didapatkan kadar air optimum sample adalah $18 \%$ seperti terlihat pada Gambar 2. Selanjutnya untuk merancang model lereng dibuat sample dengan kadar air sesuai kadar air optimum yaitu $18 \%$. 


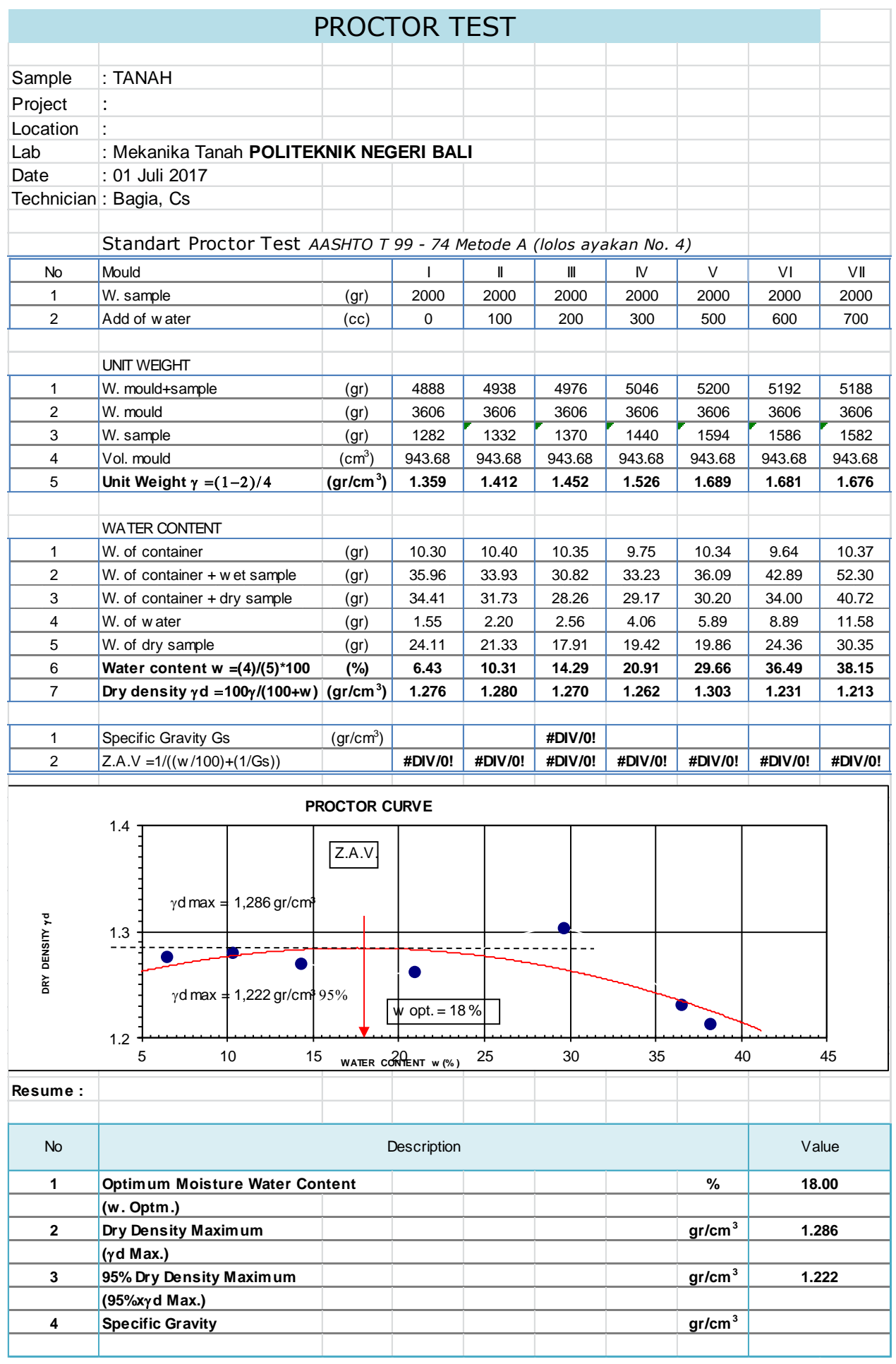

Gambar 2. Grafik Proctor Test

\section{Pembuatan sampel Uji}

Pembuatan benda uji yaitu dengan membuat tabung sampel yang akan dipakai untuk menguji permeabilitas tanah. Dilakukan variasi tiga jenis benda uji yaitu benda uji yang tidak dipadatkan, benda uji uji yang dipadatkan sesuai dengan standar proctor dan yang ketiga adalah benda uji yang tidak dipadatkan kemudian 
diinjeksi dengan semen. Semua benda uji dirancang pada kadar air optimum yaitu $18 \%$. Kada air ini adalah kada air tanah tersebut yang paling baik apabila dilakukan pemadatan. Semua benda uji di cari berat volume dan angka pori. Benda uji jenis pertama yaitu yang tidak dipadatkan diuji koefisien permeabilitasnya. Kondisi ini adalah sebagai kondisi awal atau kondisi pembanding. Kemudian benda uji jenis kedua yaitu benda uji yang dipadatkan dan benda uji jenis ketiga yaitu benda uji yang diinjeksi semen juga diukur kofisien permeabilitasnya.

\section{Uji Permeabilitas Tanah}

Dilakukan pengujian terhadap tanah yang asli dengan tanah yang diinjeksi terhadap semen. Data awal tentang sample disajikan pada Tabel 1 di bawah. Pada Tabel 1 diperlihatkan kondisi awal sample dengan berat volume $0,84 \mathrm{gr} / \mathrm{cm}^{3}$. Kondisi tanah tidak dipadatkan yaitu ditimbun begitu saja tanpa perlakuan. Kemudian tabung ini dikelompokan menjadi dua bagian yaitu untuk contoh yang asli tanpa perlakuan dan contoh yang akan diinjeksi dengan semen.

Dari pengujian didapatkan rata - rata koefisien permeabilitas tanah yang tidak diinjeksi semen adalah $0,000809 \mathrm{~cm} /$ detik. Selanjutnya untuk tabung yang diinjeksi semen dilakukan uji permeabiltas dengan hasil seperti pada tabel-tabel 3 di bawah.

Tabel 1. Data Awal Sampel

\begin{tabular}{|c|c|c|c|c|c|c|c|c|}
\hline $\begin{array}{c}\text { No } \\
\text { Tabung }\end{array}$ & $\begin{array}{l}\text { Tinggi } \\
\text { Tabung }\end{array}$ & $\begin{array}{c}\text { Diameter } \\
\text { Tabung }\end{array}$ & $\begin{array}{c}\text { Berat Tabung } \\
\text { Kosong }\end{array}$ & $\begin{array}{c}\text { Berat } \\
\text { Tabung dan } \\
\text { Tanah }\end{array}$ & Berat Tanah & $\begin{array}{l}\text { Volume } \\
\text { Tanah }\end{array}$ & $\begin{array}{l}\text { Berat } \\
\text { Volume }\end{array}$ & $\begin{array}{c}\text { Luas } \\
\text { Penampang }\end{array}$ \\
\hline & $\mathrm{Cm}$ & $\mathrm{Cm}$ & Gram & Gram & Gram & $\mathrm{Cm}^{3}$ & $\mathrm{Gram} / \mathrm{Cm}^{3}$ & $\mathrm{Gram} / \mathrm{Cm} 2$ \\
\hline 1 & 19.8 & 7 & 186 & 838 & 652 & 761.61 & 0.86 & 38.47 \\
\hline 2 & 20 & 7 & 186 & 828 & 642 & 769.30 & 0.83 & 38.47 \\
\hline 3 & 20 & 7 & 187 & 826 & 639 & 769.30 & 0.83 & 38.47 \\
\hline 4 & 20 & 7 & 187 & 846 & 659 & 769.30 & 0.86 & 38.47 \\
\hline 5 & 19.8 & 7 & 186 & 813 & 627 & 761.61 & 0.82 & 38.47 \\
\hline 6 & 19.9 & 7 & 186 & 819 & 633 & 765.45 & 0.83 & 38.47 \\
\hline 7 & 20 & 7 & 186 & 829 & 643 & 769.30 & 0.84 & 38.47 \\
\hline 8 & 20 & 7 & 186 & 819 & 633 & 769.30 & 0.82 & 38.47 \\
\hline 9 & 20 & 7 & 185 & 824 & 639 & 769.30 & 0.83 & 38.47 \\
\hline 10 & 19.9 & 7 & 185 & 828 & 643 & 765.45 & 0.84 & 38.47 \\
\hline & & & & & \multicolumn{2}{|c|}{ Berat volume rata rata } & 0.84 & \\
\hline
\end{tabular}


Tabel 2 (a) : Uji Permeabilitas Sampel Tabung No 4

$$
-k=\frac{Q \cdot L}{h \cdot A \cdot t}
$$

$$
k=2,303 \frac{a L}{A t} \ln \frac{h}{h}
$$

\begin{tabular}{|c|c|c|c|c|c|c|c|}
\hline \multirow{2}{*}{$\begin{array}{c}\text { Sampel } \\
\text { No } 4 \\
\text { Pembacaan } \\
\text { No }\end{array}$} & \multicolumn{2}{|c|}{ Tanpa Injeksi semen } & \multicolumn{3}{|c|}{ Pemampatan } & \multirow[b]{2}{*}{$\mathrm{k}$} & \multirow[t]{2}{*}{$\mathrm{cm}$} \\
\hline & $\mathrm{L}$ & $\mathrm{h}$ & A & $\mathrm{t}$ & $\mathrm{Q}$ & & \\
\hline & $\mathrm{cm}$ & $\mathrm{cm}$ & $\mathrm{cm}^{2}$ & detik & $\mathrm{cm}^{3}$ & $\mathrm{~cm} /$ detik & \\
\hline 1 & 13 & 53.5 & 38.47 & 814 & 100 & 0.00077607 & \\
\hline 2 & 13 & 53.5 & 38.47 & 1362 & 150 & 0.00069573 & \\
\hline 3 & 13 & 53.5 & 38.47 & 1764 & 200 & 0.00071623 & \\
\hline 4 & 13 & 53.5 & 38.47 & 930 & 100 & 0.00067927 & \\
\hline 5 & 13 & 53.5 & 38.47 & 1435 & 150 & 0.00066033 & \\
\hline 6 & 13 & 53.5 & 38.47 & 1890 & 200 & 0.00066849 & \\
\hline 7 & 13 & 53.5 & 38.47 & 3275 & 350 & 0.00067512 & \\
\hline 8 & 13 & 53.5 & 38.47 & 4679 & 500 & 0.00067506 & \\
\hline 9 & 13 & 53.5 & 38.47 & 1951 & 200 & 0.00064758 & \\
\hline \multicolumn{6}{|c|}{ Rata Rata nilai k (koefisien permeabilitas) } & 0.00068821 & \\
\hline
\end{tabular}

\begin{tabular}{|c|c|c|c|c|c|c|c|}
\hline \multirow{2}{*}{\begin{tabular}{|c|} 
Sampel \\
No 2 \\
Pembacaa \\
n No \\
\end{tabular}} & \multicolumn{2}{|c|}{ Tanpa Injeksi semer } & \multicolumn{3}{|c|}{ Pemampatan } & \multirow{2}{*}{$\begin{array}{l}7 \\
\mathrm{k}\end{array}$} & \multirow[t]{2}{*}{$\mathrm{cm}$} \\
\hline & $\mathrm{L}$ & $\mathrm{h}$ & $A$ & $\mathrm{t}$ & $Q$ & & \\
\hline & $\mathrm{cm}$ & $\mathrm{cm}$ & $\mathrm{cm}^{2}$ & detik & $\mathrm{cm}^{3}$ & $\mathrm{~cm} /$ detik & \\
\hline 1 & 13 & 53.4 & 38.47 & 1215 & 100 & 0.00052091 & \\
\hline 2 & 13 & 53.4 & 38.47 & 2657 & 200 & 0.0004764 & \\
\hline 3 & 13 & 53.4 & 38.47 & 1318 & 100 & 0.0004802 & \\
\hline 4 & 13 & 53.4 & 38.47 & 2105 & 150 & 0.000451 & \\
\hline 5 & 13 & 53.4 & 38.47 & 2890 & 200 & 0.00043799 & \\
\hline 6 & 13 & 53.4 & 38.47 & 4588 & 200 & 0.00027589 & \\
\hline \multicolumn{6}{|c|}{ Rata Rata nilai k (koefisien permeabilitas) } & 0.0004404 & \\
\hline
\end{tabular}

Tabel 2 (b) : Uji Permeabilitas Sampel Tabung No 2

\begin{tabular}{|c|c|c|c|c|c|c|c|}
\hline \multirow{2}{*}{$\begin{array}{c}\text { Sampel } \\
\text { No } 7 \\
\text { Pembacaa } \\
\text { n No }\end{array}$} & \multicolumn{2}{|c|}{ Tanpa Injeksi semer } & \multicolumn{3}{|c|}{ Pemampatan } & \multirow{2}{*}{$\begin{array}{l}7 \\
\mathrm{k}\end{array}$} & \multirow[t]{2}{*}{$\mathrm{cm}$} \\
\hline & L & $\mathrm{h}$ & A & $\mathrm{t}$ & $Q$ & & \\
\hline & $\mathrm{cm}$ & $\mathrm{cm}$ & $\mathrm{cm}^{2}$ & detik & $\mathrm{cm}^{3}$ & $\mathrm{~cm} /$ detik & \\
\hline 1 & 13 & 53.7 & 38.47 & 690 & 100 & 0.00091212 & \\
\hline 2 & 13 & 53.7 & 38.47 & 954 & 150 & 0.00098957 & \\
\hline 3 & 13 & 53.7 & 38.47 & 1273 & 200 & 0.00098879 & \\
\hline 4 & 13 & 53.7 & 38.47 & 2854 & 450 & 0.00099234 & \\
\hline 5 & 13 & 53.7 & 38.47 & 1388 & 200 & 0.00090687 & \\
\hline 6 & 13 & 53.7 & 38.47 & 2444 & 350 & 0.0009013 & \\
\hline 7 & 13 & 53.7 & 38.47 & 3487 & 500 & 0.00090245 & \\
\hline 8 & 13 & 53.7 & 38.47 & 1438 & 200 & 0.00087534 & \\
\hline 9 & 13 & 53.7 & 38.47 & 3503 & 500 & 0.00089832 & \\
\hline \multicolumn{6}{|c|}{ Rata Rata nilai k (koefisien permeabilitas) } & 0.00092968 & \\
\hline
\end{tabular}

Tabel 2 (c) : Uji Permeabilitas Sampel Tabung No 7 
Tabel 3 (a) : Uji Permeabilitas Tabung No 9

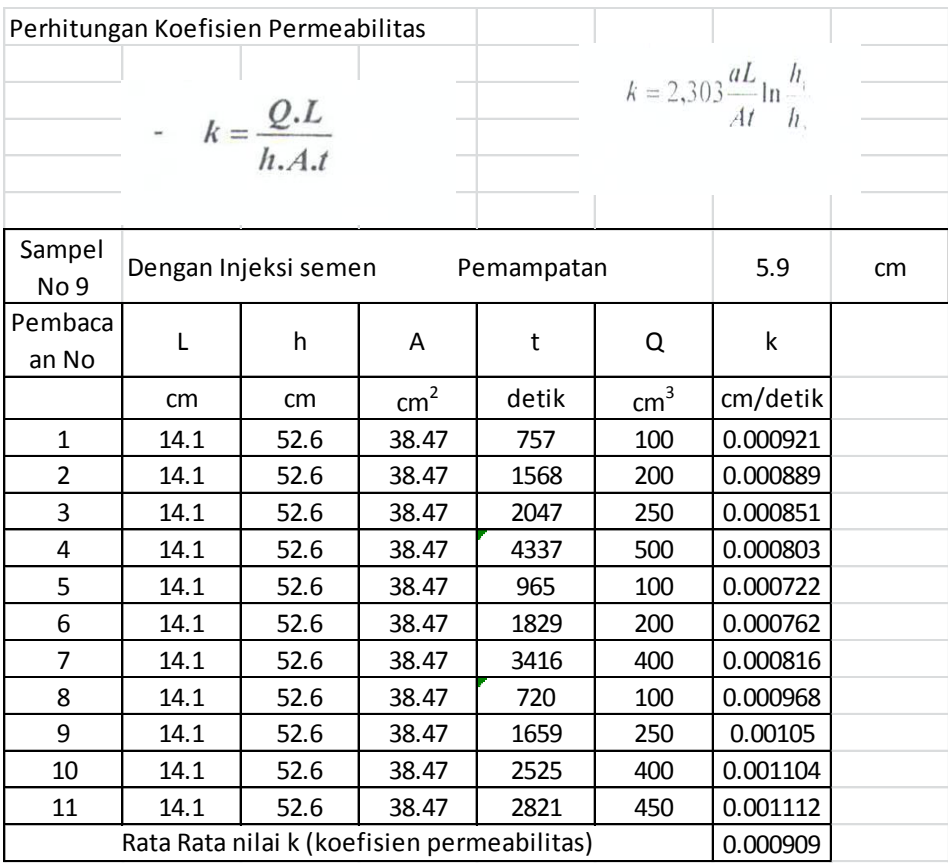

Tabel 3 (b) : Uji Permeabilitas Tabung No 5

\begin{tabular}{|c|c|c|c|c|c|c|c|}
\hline \multirow{2}{*}{\begin{tabular}{|c|}
$\begin{array}{c}\text { Sampel } \\
\text { No } 5\end{array}$ \\
Pembaca \\
an No \\
\end{tabular}} & \multicolumn{3}{|c|}{ Dengan Injeksi semen } & \multicolumn{2}{|c|}{ emampatan } & \multirow{2}{*}{$\frac{7.5}{k}$} & \multirow[t]{2}{*}{$\mathrm{cm}$} \\
\hline & $\mathrm{L}$ & $\mathrm{h}$ & A & $\mathrm{t}$ & $Q$ & & \\
\hline & $\mathrm{cm}$ & $\mathrm{cm}$ & $\mathrm{cm}^{2}$ & detik & $\mathrm{cm}^{3}$ & $\mathrm{~cm} /$ detik & \\
\hline 1 & 12.3 & 53.8 & 38.47 & 1364 & 300 & 0.001307 & \\
\hline 2 & 12.3 & 53.8 & 38.47 & 1482 & 250 & 0.001003 & \\
\hline 3 & 12.3 & 53.8 & 38.47 & 2694 & 450 & 0.000993 & \\
\hline 4 & 12.3 & 53.8 & 38.47 & 1704 & 250 & 0.000872 & \\
\hline 5 & 12.3 & 53.8 & 38.47 & 2388 & 350 & 0.000871 & \\
\hline 6 & 12.3 & 53.8 & 38.47 & 2709 & 400 & 0.000878 & \\
\hline 7 & 12.3 & 53.8 & 38.47 & 1129 & 150 & 0.00079 & \\
\hline 8 & 12.3 & 53.8 & 38.47 & 2454 & 350 & 0.000848 & \\
\hline \multicolumn{6}{|c|}{ Rata Rata nilai k (koefisien permeabilitas) } & 0.000945 & \\
\hline
\end{tabular}

Tabel 3 (c) : Uji Permeabilitas Tabung No 3

\begin{tabular}{|c|c|c|c|c|c|c|c|}
\hline $\begin{array}{c}\text { Sampel } \\
\text { No 3 }\end{array}$ & Dengan Injeksi semen & \multirow{2}{*}{6.2} & $\mathrm{~cm}$ \\
\hline $\begin{array}{c}\text { Pembaca } \\
\text { an No }\end{array}$ & $\mathrm{L}$ & $\mathrm{h}$ & $\mathrm{A}$ & $\mathrm{t}$ & $\mathrm{Q}$ & $\mathrm{k}$ & \\
\hline & $\mathrm{cm}$ & $\mathrm{cm}$ & $\mathrm{cm}^{2}$ & detik & $\mathrm{cm}^{3}$ & $\mathrm{~cm} /$ detik & \\
\hline 1 & 13.8 & 54 & 38.47 & 3493 & 200 & 0.00038 \\
\hline 2 & 13.8 & 54 & 38.47 & 6211 & 300 & 0.000321 \\
\hline 3 & 13.8 & 54 & 38.47 & 7751 & 350 & 0.0003 \\
\hline \multicolumn{7}{|c|}{ Rata Rata nilai k (koefisien permeabilitas) } & 0.000334 \\
\hline
\end{tabular}


Tabel 3 (d) : Uji Permeabilitas Tabung No 6

\begin{tabular}{|c|c|c|c|c|c|c|c|}
\hline \multirow{2}{*}{$\begin{array}{c}\text { Sampel } \\
\text { No } 6 \\
\begin{array}{c}\text { Pembaca } \\
\text { an No }\end{array}\end{array}$} & \multicolumn{3}{|c|}{ Dengan Injeksi semen } & \multicolumn{2}{|c|}{ emampatan } & \multirow{2}{*}{$\frac{6.5}{k}$} & \multirow[t]{2}{*}{$\mathrm{cm}$} \\
\hline & $\mathrm{L}$ & $\mathrm{h}$ & A & $\mathrm{t}$ & Q & & \\
\hline & $\mathrm{cm}$ & $\mathrm{cm}$ & $\mathrm{cm}^{2}$ & detik & $\mathrm{cm}^{3}$ & $\mathrm{~cm} /$ detik & \\
\hline 1 & 19.9 & 54 & 38.47 & 1691 & 200 & 0.001133 & \\
\hline 2 & 19.9 & 54 & 38.47 & 4599 & 400 & 0.000833 & \\
\hline 3 & 19.9 & 54 & 38.47 & 4029 & 150 & 0.000357 & \\
\hline \multicolumn{6}{|c|}{ Rata Rata nilai k (koefisien permeabilitas) } & 0.000774 & \\
\hline
\end{tabular}

Tabel 3 (e) : Uji Permeabilitas Tabung No 10

\begin{tabular}{|c|c|c|c|c|c|c|c|}
\hline \multirow{2}{*}{$\begin{array}{c}\text { Sampel } \\
\text { No } 10 \\
\begin{array}{c}\text { Pembaca } \\
\text { an No }\end{array}\end{array}$} & \multicolumn{3}{|c|}{ Dengan Injeksi semen } & \multicolumn{2}{|c|}{ emampatan } & \multirow{2}{*}{$\frac{7.7}{k}$} & \multirow[t]{2}{*}{$\mathrm{cm}$} \\
\hline & $\mathrm{L}$ & $\mathrm{h}$ & A & $\mathrm{t}$ & Q & & \\
\hline & $\mathrm{cm}$ & $\mathrm{cm}$ & $\mathrm{cm}^{2}$ & detik & $\mathrm{cm}^{3}$ & $\mathrm{~cm} /$ detik & \\
\hline 1 & 12.2 & 53.6 & 38.47 & 781 & 100 & 0.000758 & \\
\hline 2 & 12.2 & 53.6 & 38.47 & 1561 & 200 & 0.000758 & \\
\hline 3 & 12.2 & 53.6 & 38.47 & 3410 & 400 & 0.000694 & \\
\hline 4 & 12.2 & 53.6 & 38.47 & 7010 & 100 & $8.44 \mathrm{E}-05$ & \\
\hline \multicolumn{6}{|c|}{ Rata Rata nilai k (koefisien permeabilitas) } & 0.000574 & \\
\hline
\end{tabular}

Tabel 3 (f) : Uji Permeabilitas Tabung No 8

\begin{tabular}{|c|c|c|c|c|c|c|c|}
\hline \multirow{2}{*}{\begin{tabular}{|c}
$\begin{array}{c}\text { Sampel } \\
\text { No } 8\end{array}$ \\
$\begin{array}{c}\text { Pembaca } \\
\text { an No }\end{array}$
\end{tabular}} & \multicolumn{3}{|c|}{ Dengan Injeksi semen } & \multicolumn{2}{|c|}{ emampatan } & \multirow{2}{*}{$\frac{5.5}{k}$} & \multirow[t]{2}{*}{$\mathrm{cm}$} \\
\hline & L & $\mathrm{h}$ & A & $\mathrm{t}$ & Q & & \\
\hline & $\mathrm{cm}$ & $\mathrm{cm}$ & $\mathrm{cm}^{2}$ & detik & $\mathrm{cm}^{3}$ & $\mathrm{~cm} /$ detik & \\
\hline 1 & 14.5 & 54 & 38.47 & 1578 & 300 & 0.001327 & \\
\hline 2 & 14.5 & 54 & 38.47 & 1540 & 250 & 0.001133 & \\
\hline 3 & 14.5 & 54 & 38.47 & 2790 & 450 & 0.001126 & \\
\hline \multicolumn{6}{|c|}{ Rata Rata nilai k (koefisien permeabilitas) } & 0.001195 & \\
\hline
\end{tabular}

Dari pembuatan injeksi semen terlihat bahwa tidak semua tabung yang diinjeksi semen menunjukkan keberhasilan prilakunya. Ini disebabkan oleh metode injeksi yang belum tepat sehingga menghasilkan injeksi yang seragam. Dari injeksi yang berhasil dilkukakn didapat koefisien permeabilitas tanah rata rata adalah: $0,000554 \mathrm{~cm} /$ detik. Nilai ini didapat dari tabung no 4 dan tabung no 5. Dengan demikian terjadi penurunan koefisien permeabilitas dari yang tanpa injeksi dengan yang diinjeksi. Penurunannya yaitu dari 0,000809 $\mathrm{cm} /$ detik menjadi $0,000554 \mathrm{~cm} /$ detik, atau terjadi penurunan sebesar 31,5\%. Penurunan koefisien permeabilitas menunjukkan tanah menjadi lebih kedap air dan angka porinya menjadi lebih kecil. Selanjutnya akan berpengaruh terhadap masuknya air yang dapat mengakibatkan lereng menjadi longsor.

\section{SIMPULAN}

Dari hasil pengujian dan pembahasan di atas maka dapat disimpukan bahwa terjadi penurunan koefisien permeabilitas tanah dari tanah asli dibandingkan dengan tanah yang diinjeksi semenyaitu sebesar 31,5\%. 
Dengan penurunan koefisien permeabilitas menunjukkan pori tanah menurun dan tanah menjadi lebih kedap air.

\section{DAFTAR PUSTAKA}

Das, B.M., 2006, Principles of Geotechnical Engineering. Canada: Thomson.

Rahardjo, H., et al., 2005, Response of a residual soil slope to rainfall. Canadian Geotechnical Journal. 42(2): p. 340-351.

Chowdhury, R., 2010, Geotechnical Slope Analysis. Netherlands: CRC Press/Balkema.

Roy E. Hunt, P.E., P.G., 2007, Geologic Hazards A Field Guide for Geotechnical Engineers. New York: Taylor \& Francis Group.

kmb27, Ambrol 100 Meter, Kedalaman 70 Meter, in Bali Post. 2016, Bali Post: Denpasar. p. 1.

Arya, I.W., I.W. Wiraga, and I.G. Suryanegara, 2018, Effect of cement injection on sandy soil slope stability, case study: slope in Petang district, Badung regency. Journal of Physics: Conference Series. 953(1).

Knappett, J.A. and R.F. Craig, 2012, Craig's Soil Mechanics. London: Spon Press.

Cheng, Y.M. and C.K. Lau, 2008, Slope Stability Analysis and Stabilization. London: Routledge.

Leroueil, S. and L. Picarelli, 2012, Assessment of Slope Stability. Geotechnical Engineering State of the Art and Practice: Keynote Lectures from GeoCongress 2012. 226: p. 122.

Guo, D., M. Hamada, and H. Jia. 2013, Influential Factors on Slope Stability and Landslide Mobility. in IACGE 2013: Challenges and Recent Advances in Geotechnical and Seismic Research and Practices. ASCE.

Mentes, G., 2016, Observing Slope Stability Changes on the Basis of Tilt and Hydrologic Measurements.

Le, T.M.H., et al., 2015, Stability and failure mass of unsaturated heterogeneous slopes. Canadian Geotechnical Journal. 52(11): p. 1747-1761.

Ali, A., et al., 2014, Simplified quantitative risk assessment of rainfall-induced landslides modelled by infinite slopes. Engineering Geology. 179: p. 102-116.

White, J.A. and D.I. Singham, 2012, Slope Stability Assessment using Stochastic Rainfall Simulation. Procedia Computer Science. 9: p. 699-706.

Zhang, G., et al., 2012, Effect study of cracks on behavior of soil slope under rainfall conditions. Soils and Foundations. 52(4): p. 634643.

Mochtar, I.B. 2012, Kenyataan Lapangan Sebagai Dasar Untuk Usulan Konsep Baru Tentang Analisa Kuat - Geser Tanah dan Kestabilan Lereng. in Geotechnical Challenges in Presnt and Coming Nationwide 
Construction Activities. Jakarta: HATTI.

Mochtar, I.B. 2016, Cracks In Soil and Their Implication For Geotechnical Engineering. in Geotechnical Role to Accelerete Infrasrtucture Construction in Indonesia. Jakarta: HATTI.

El-Ramly, H., N. Morgenstern, and D. Cruden, 2002, Probabilistic slope stability analysis for practice. Canadian Geotechnical Journal. 39(3): p. 665-683.

Chen, H.X., et al., 2016, A physicallybased multi-hazard risk assessment platform for regional rainfall-induced slope failures and debris flows. Engineering Geology. 203: p. 15-29.

Gray, D. 2013, Influence of Slope Morphology on the Stability of Earthen Slopes. in Geo-Congress 2013: Stability and Performance of Slopes and Embankments III. ASCE.

Tallon, L., et al., 2011, Unsaturated sloping layered soil cover system: Field investigation. Canadian Journal of Soil Science. 91(2): p. 161-168.

Li, X., et al., 2016, Assessment of Slope Stability in the Monitoring Parameter Space. Journal of Geotechnical and Geoenvironmental Engineering: p. 04016029.

Dhatrak, A. and G. Bhagat, 2016, Behaviour of Long Pile in
Reinforced Slope Subjected to Inclined Load. International Journal of Engineering Science. 2551.

Fuggini, C., et al., 2016, Innovative Approach in the Use of Geotextiles for Failures Prevention in Railway Embankments. Transportation Research Procedia. 14: p. 18751883.

Palmeira, E.M. and J. Tatto, 2015, Behaviour of geotextile filters in armoured slopes subjected to the action of waves. Geotextiles and Geomembranes. 43(1): p. 46-55.

Narejo, D., et al., 2013, A monolithic layered nonwoven-woven geotextile for use with drainage geocomposites in coal combustion residual projects. Geotextiles and Geomembranes. 37: p. 16-22.

Holtz, R.D. and W.D. Kovacs, 1981, An Introduction to Geotechnical Engineering. New Jersey: Prentice-Hall Inc.

Redana, I.W., 2011, Mekanika Tanah. Denpasar: Udayana University Press.

Prof. Dr. A. Muri Yusuf, M.P., 2014, Metode Penelitian: Kuantitatif, Kualitatif \& Penelitian Gabungan. Vol. 2. Jakarta: Prenada Media Group.

Subagyo, P., 2011, Statisitika Terapan.

Vol. 2. Yogyakarta: BPFEYogyakarta. 